\title{
Family Empowerment Strategy toward Business Independency of UPPKS Members in DKI Jakarta
}

\author{
Lailatur Rohmah $^{1}$, Pudji Muljono ${ }^{2}$, Ninuk Purbaningsih ${ }^{2}$ and Aida Vitayala ${ }^{2}$ \\ ${ }^{1}$ STIAMI Jakarta Institute of Social Sciences and Management \\ Jl. Soeprapto No. 62 Biromaru Sigi Regency 93772, Indonesia \\ ${ }^{2}$ Faculty of Human Ecology, Bogor Agricultural University \\ Jl. Lingkar Akademik, IPB Dramaga Campus Bogor, 16680, Indonesia \\ E-mail: 1ailarahma1@yahoo.com; pudjimujono@gmail.com; npurnaningsih@gmail.com; aidavitayala@yahoo.com
}

DOI: $10.31364 / \mathrm{SCIRJ} / \mathrm{v} 6.19 .2018 . P 0918569$

http://dx.doi.org/10.31364/SCIRJ/v6.i9.2018.P0918569

\begin{abstract}
This study aims at analyzing the relationship between the level of empowerment of UPPKS' members and their characteristics and to discuss strategies to empower poor family. Data was collected by using questionnaires towards 192 UPPKS members. These data were then estimated by using by descriptive test, different test of Mann Whitney and Rank Spearman test. The study found that UPPKS members in five regions of Jakarta had different levels of empowerment and characteristics in accessing and managing their business. There are significant differences in age and business experiences in accessing capital, level of education, capital owned, and to access technology. The level of empowerment of members in accessing capital, information, market opportunities and business networks are in the medium category, while in accessing technology is still low. However, the overall relationship of empowerment and its characteristics shows factors that are significantly related are age, level of education, owned capital, business experience and business motivation. Therefore, strategies to improve the poor family under the UPPKS program can be undertaken by (1) enhancing the empowerment process specified in counseling and training; (2); enhancing group roles; and (3) strengthening support from several institutions. This study also confirms that increasing the empowerment of members is very important because the ability of UPPKS members to build and gain access in several institutions can lead to business independence. However, efforts to improve the empowerment of UPPKS members require a different approach to all aspects of technical and non-technical capabilities. Thus, much remain to be done.
\end{abstract}

Keywords: empowerment, characteristics, UPPKS, poverty, strategy

\section{INTRODUCTION}

Poor families basically consist of families whose income and economic income is relatively low. The low income and economic income of the family is due to the low or not owned family empowerment (Astriani2007). The low level of family empowerment is characterized by: (1) low levels of knowledge due to low levels of education, (2) mental attitudes that are still traditional without being accompanied by the desire to progress and develop, and (3) inadequate skills to be able to compete with life.

The low level of income of poor families has an impact on their low well-being which places them as people with low levels of independence. Thus in order to build or improve the welfare of poor families, it is necessary to be supported by the role of the Government, one of which is by increasing the potential of the family (Hardiansyah 1997). This family empowerment in the economic field is one of the efforts that can be done to increase family potential in terms of welfare. Family empowerment in the economic field means providing opportunities for families to be able to improve their abilities and skills to be able to take advantage of existing job opportunities.

Theoretically the empowerment process for poor families in general is very dependent on two things, namely (1) internal strength, and (2) the need for intervention from external forces, namely the forces that are outside themselves. The strength that exists in him concerns all the potential possessed by UPPKS members such as the level of motivation, skills, needs, knowledge, mental attitude, and so on. The strength that comes from outside is related to the help or stimulus that encourages them to be more powerful.

Empowerment patterns that have been carried out, both the Government, the private sector and other parties emphasize and emphasize charity programs (donations, assistance and charity) or more to the program how to give something like BLT and others (Adnan 2012). On the other hand, there are still very few empowerment programs for citizens who are shaped to empower poor families to be free from their helplessness. Because the pattern of empowerment in the form of charity is very possible to reap failure, because it will create dependency and in practice this pattern will only help poor families in the short term. After the aid runs out they are again poor and helpless. This condition encourages a study that aims to produce a formula about family empowerment towards business independence through the right UPPKS group with the strategies raised, so that the results are expected to be a model for members in other UPPKS groups. Referring to the importance of empowering members and their relation to business independence, the purpose of this study is (1) to analyze the level of empowerment of 
members; and (2) Formulating effective strategies for family empowerment towards business independence.

\section{METHOD}

The study was conducted in five regions in DKI Jakarta. The determination of the location of the research was carried out purposively in the central business district. Data collection is carried out from February to May 2017.

Determination of the sample in this study was carried out in several steps (multistage sampling). The first step is to deliberately choose the area that is the center of the business. The second step is in each selected region that has already entered AKU members. The third step is selected by UPPKS members who are identified as active businesses running their own business. Furthermore, the prospective respondent or sample is determined by Proposive method (Table 1).

Table 1 Number of members and groups of UPPKS based on on Location in Jakarta

\begin{tabular}{|l|c|c|c|c|c|c|}
\hline & $\begin{array}{c}\text { South } \\
\text { JKT }\end{array}$ & $\begin{array}{c}\text { East } \\
\text { JKT }\end{array}$ & $\begin{array}{c}\text { Centr } \\
\text { al JKT }\end{array}$ & $\begin{array}{c}\text { North } \\
\text { JKT }\end{array}$ & $\begin{array}{c}\text { West } \\
\text { JKT }\end{array}$ & Total \\
\hline $\begin{array}{l}\text { Distric } \\
t\end{array}$ & 8 & 10 & 10 & 6 & 9 & 43 \\
\hline $\begin{array}{l}\text { Sub- } \\
\text { distric } \\
t\end{array}$ & 40 & 56 & 59 & 30 & 53 & 238 \\
\hline Group & 155 & 199 & 192 & 153 & 170 & 869 \\
\hline $\begin{array}{l}\text { Memb } \\
\text { er }\end{array}$ & 35 & 55 & 40 & 35 & 27 & 192 \\
\hline
\end{tabular}

Data collected in the form of primary data through interviews using structured questionnaires to respondents' UPPKS members. Besides that, direct observations were made in the field and daily records. Searching report documents from relevant agencies (BKKBN, BPMPKB and KASI-DKI) (UPPKS membership, KB participation, frequency of access to capital and type of business), NGOs / social organizations involved in UPPKS (AKU, Extension Institutions), as secondary data.

\section{Data analysis}

The collected data were analyzed using descriptive statistics and inferential statistical analysis. The variables used in this study are the characteristics of UPPKS members including: Age, education level, type of family planning followed, training, income, capital, business units, business experience and business motivation. The empowerment of members includes: the ability to access capital, the ability to access information and market opportunities, the ability to access technology, the ability to access business networks, and the ability to access resources. Indicators and parameters are analyzed using a scoring system. Giving a score follows a Likert scale with a scale of 1 to 3 . The score obtained from the respondents is then determined in the range of scales or hoses in the category of high, medium, low. To determine the level of capacity of farmers and their characteristics, using formulas (Umar, 2006), namely:

To find out the relationship between characteristic variables to capacity variables, it was done by Rank Spearman correlation, with data processing tools using Statistical Product and Service Solution (SPSS) software. The formula is as follows: (Rianse, 2008)

\section{Range $=\underline{\text { Maximum value }- \text { minimum value }}$ Number of answer category}

Measuring the difference between the empowerment of members and their characteristics in five regions in DKI Jakarta, a different Mann Whitney test was conducted, according to the type of data used in the form of ordinal data (Rianse, 2008), using the formula:

$$
\begin{aligned}
& \mathrm{U}_{1}=\mathrm{n}_{1} \times \mathrm{n}_{2}+\frac{\mathrm{n}_{2\left(\mathrm{n}_{2}+1\right)}}{2}-\sum \mathrm{R}_{2} \\
& \mathrm{U}_{2}=\mathrm{n}_{1} \times \mathrm{n}_{2}+\frac{\mathrm{n}_{1\left(\mathrm{n}_{1}+1\right)}}{2}-\sum \mathrm{R}_{1}
\end{aligned}
$$

To find out the relationship between characteristic variables to capacity variables, it was done by Rank Spearman correlation, with data processing tools using Statistical Product and Service Solution (SPSS) software. The formula is as follows: (Rianse, 2008)

$$
r s=1-\frac{6 \sum_{i-1}^{n} d i^{2}}{n^{3}}
$$

$$
\begin{aligned}
& \text { Note: } \\
& r \mathrm{~s}=\text { estimated correlation coefficient } \\
& \mathrm{di}=\text { differences of ranking } \\
& \mathrm{n}=\text { number of respondents }
\end{aligned}
$$

\section{RESULTS AND DISCUSSION \\ Characteristics of Members}

Individual characteristics are part of personal characteristics and are inherent in a person. These characteristics underlie someone's behavior in work situations and other situations (Rogers and Shoemaker 1981). Mardikanto (1993) argues that individual characteristics are characteristics inherent in a person and related to aspects of life, such as; age, gender, position, position, social status, and religion. In relation to the process of diffusion of innovation, Slamet (2003) suggests that age, education, socioeconomic status, patterns of relationships and attitudes are individual factors that influence the process of diffusion of innovation (Lionberger 1960) suggests that individual/personal characteristics related to all aspects of life and the environment are: age, education and psychological characteristics. Psychological characteristics are rationality, mental flexibility, orientation to business as a business and ease of accepting innovation.

Conceptually individual characteristics are all characteristics inherent in someone who can be different 
from others. Based on the concept, the characteristics of UPPKS members are the characteristics inherent in individual members who can distinguish them from other members. Each individual member has their own characteristics that are different from each other. Agussabti (2002) identifies seven individual characteristics that are considered to have an influence in empowering members to foster independence in decision making, namely: (1) age, (2) experience working (3) achievement motivation, (4) aspiration, (5) perception, (6) courage to take risks, and (7) creativity.

The results of the analysis of the characteristics of UPPKS members in the five municipalities in Table 2 show that the level of education, training followed, business experience and business motivation are almost the same, namely at the medium level. For income and capital owned by the low category, while for the high category age. Age from an average member above 50 years (59.48 percent). The older a person will be more skilled in carrying out the task, the smaller the level of error in carrying out his work. This happens because one of the factors of excess human beings from other creatures is the ability to learn from experience, especially experiences that end in error.

The average level of education is 54.8 percent with high school (high school) education, so that the education achieved indicates that the member is good at finding out what business is in line with market needs, this is in accordance with Prawiranegara (2016) and Ruhimat (2015), indicating that the higher the level of education of a person, it will influence the way of thinking, attitudes and behavior towards a more rational way of accepting and understanding the technological innovations that are obtained. Training, Supriat (1997) states that non-formal education can be in the form of counseling, training, courses, as well as other forms of technical skills with the aim of increasing intelligence and skills. The training obtained by members (49.1 percent), members for 3 years only mostly attended training 3 to 5 times, which followed above 5 times $(3.86$ percent). There are also members who answer rarely attend training, even tend to never attend training. Thus, it is necessary to further increase empowerment through counseling and training that is appropriate to the needs of UPPKS members. Business experience is something that has been experienced, lived, felt in carrying out its business activities by mobilizing energy and mind to achieve the desired income. 64.86 percent experienced approximately 3 to 5 years, 23.28 percent experienced more than 5 years, only 11.86 percent experience level was less than 3 years. This means that most UPPKS members experience 3 to 5 years of experience in doing business, so that they have experienced a ups and downs, a bit of a bitter effort, and a profit and loss. Motivation in trying (81.8 percent), the motivation to try medium means that the majority of UPPKS members want to join the Government program in the hope of increasing their income. Low income (57.44 percent) which is less than 2 million per month. Only 18.14 percent earn more than 5 million per month.

Like South Jakarta 14.5 with superior kraf (plastic waste). East Jakarta (25 percent) with kraf (waste cloth waste), culinary, aloe vera made various foods and drinks. Central Jakarta (8.5 percent) with the cloth of the splash and the mistress of Madame Menteng. North Jakarta with fish crackers that have penetrated abroad, and finally West Jakarta with bandeng prestonya. Capital (77.56 percent) is below 1 million, this is also part of the BKKBN / KB office loan. Only 5 percent capitalized more than 4 million rupiah, 20.64 percent capitalized 2 million to 4 million rupiah. Judging from Table 2 (84.04 percent) capital is only from its own pocket, they are reluctant to borrow from the Bank because the conditions that cannot be met, and only 15 percent are borrowed from the Bank and cooperatives. Business units (34.48 percent) are small businesses, craf (kerajian), culinary, and post-harvest. KB (39.3 percent) in the form of Spiral, as a condition for participating in the UPPKS program must take part in the family planning program. The details can be seen from Table 2 below.

Table 2 Distribution of UPPKS' Members based on Characteristics in 5 Districts in Jakarta

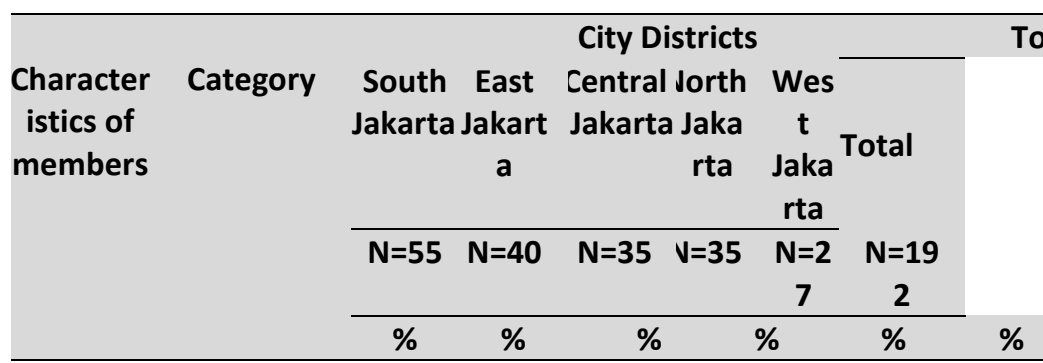

\begin{tabular}{|c|c|c|c|c|c|c|c|}
\hline Age & Young(< & - & - & - & 2,9 & & 0,5 \\
\hline Average $=$ & 30) & 32,7 & 37,5 & 34,3 & 37,1 & 58 & 39,9 \\
\hline 52 & $\begin{array}{l}\text { Adult30- } \\
50 \\
\text { Old (>50) }\end{array}$ & 67,3 & 62,5 & 65,7 & 60,0 & $41, !$ & 59 \\
\hline $\begin{array}{l}\text { Education } \\
\text { al Level }\end{array}$ & $\begin{array}{l}\text { Eletr-Jnr } \\
\text { School }\end{array}$ & 27,3 & 30 & 38,9 & 38,2 & 33,3 & 33,5 \\
\hline \multirow[t]{2}{*}{$\begin{array}{l}\text { Average }= \\
2\end{array}$} & $\begin{array}{l}\text { Senior } \\
\text { high S. }\end{array}$ & 58,2 & 50 & 52,8 & 50 & 6 & 54, \\
\hline & $\begin{array}{l}\text { Higher } \\
\text { education }\end{array}$ & 14,5 & 20 & 8,3 & 11,8 & 3,7 & 11, \\
\hline Type of & Spiral & 29,1 & 47,5 & 40 & 42,9 & 37 & 39,3 \\
\hline Family & Injection & 30,9 & 27,5 & 31,4 & 28,6 & 44,4 & 32,5 \\
\hline Planning & Pill\& & 40 & 25 & 28,6 & 28,5 & 18,6 & 28,1 \\
\hline
\end{tabular}

Average $=$ Condom

2,3

\begin{tabular}{|c|c|c|c|c|c|c|c|}
\hline Number & Low $(<3)$ & 65,5 & 65 & 31,4 & 40 & 33.3 & 47,0 \\
\hline $\begin{array}{l}\text { of } \\
\text { training }\end{array}$ & $\begin{array}{l}\text { Moderate } \\
(3-5)\end{array}$ & 30,9 & 25 & 68,6 & 54,3 & 66,7 & 49, \\
\hline $\begin{array}{l}\text { followed } \\
\text { Average } \\
=1,57\end{array}$ & $\begin{array}{l}\text { High (> } \\
5)\end{array}$ & 3,6 & 10 & - & 5,7 & & 3 , \\
\hline Income & Low $(<2 j t)$ & 63,5 & 55 & 62,9 & 54,3 & 51,5 & $\overline{57,4}$ \\
\hline $\begin{array}{l}\text { Average }= \\
1,6\end{array}$ & $\begin{array}{c}\text { Middle } \\
\text { (3-5jt) }\end{array}$ & 22 & 20 & 28,6 & 26,6 & 22,2 & 23,8 \\
\hline & $\begin{array}{l}\text { High(> } \\
5 j t)\end{array}$ & 14,5 & 25 & 8,5 & 19,1 & 26,3 & 18, \\
\hline apital & Low (7-9) & 74.6 & 7.5 & 38.5 & 65,7 & 81. & 77. \\
\hline
\end{tabular}




\begin{tabular}{|c|c|c|c|c|c|c|c|}
\hline $\begin{array}{l}\text { Owned } \\
\text { Average = }\end{array}$ & $\begin{array}{l}\text { Moderate } \\
(10-12)\end{array}$ & 23.6 & 20 & 11.5 & 34.3 & 18. & 21.5 \\
\hline 8.87 & $\begin{array}{l}\text { High } \\
(>12)\end{array}$ & 1.8 & 2,5 & - & - & & 0 \\
\hline Business & Food & 10.9 & 17.5 & 25.7 & 25.7 & 22. & 20. \\
\hline Unit & Snacks & 34.5 & 27.5 & 37.1 & 40 & 33.: & 34.4 \\
\hline Average $=$ & Crafts & 34.5 & 40 & 28.6 & 25.7 & 29.1 & 31. \\
\hline 2.4 & $\begin{array}{l}\text { Post- } \\
\text { Harvest }\end{array}$ & 20.1 & 15 & 8.6 & 8.6 & $14 . !$ & 13 \\
\hline Business & Low (3-6) & 5,4 & 5 & 11,5 & 11,5 & $25, !$ & 11,8 \\
\hline $\begin{array}{l}\text { Experienc } \\
\text { es }\end{array}$ & $\begin{array}{l}\text { Middle } \\
(7-9)\end{array}$ & 61,8 & 60 & 80 & 74,3 & 48 & 64,8 \\
\hline $\begin{array}{l}\text { Average } \\
=8,4\end{array}$ & High (>9) & 32,8 & 35 & 8,5 & 14,2 & $25 . !$ & 23 \\
\hline $\begin{array}{l}\text { Business } \\
\text { Motivatio }\end{array}$ & $\begin{array}{l}\text { weak } \\
(19-22)\end{array}$ & 3.7 & - & - & - & & \\
\hline \multirow[t]{2}{*}{$\begin{array}{l}\text { n Average } \\
=26,53\end{array}$} & $\begin{array}{l}\text { Middle } \\
(23-26)\end{array}$ & 69 & 90 & 88.5 & 80 & $81 . !$ & \\
\hline & $\begin{array}{l}\text { Strong(> } \\
26\end{array}$ & 27.3 & 10 & 11.5 & 20 & $18 . !$ & \\
\hline
\end{tabular}

\section{Member Empowerment}

Member empowerment is a basic element that allows a member to survive, and in a dynamic sense develop themselves and achieve progress. Community empowerment itself is the source of what in political insight is called national security. This means that if the community has a high economic capacity, then this is part of the national economic resilience.

Suharto (1997) states that powerlessness is due to several factors such as lack of economic security, lack of experience in the political arena, lack of access to information, lack of financial support, lack of training and physical and emotional tensions. Solomon in Suharto (1997) saw that powerlessness can come from internal and external factors. Powerlessness can come from negative self-assessors, negative interactions with the environment or stemming from blockages and obstacles that come from a larger environment.

Member empowerment can be realized through active participation of members facilitated by empowerment actors. The main objectives of empowerment are those who are weak and have no power, strength / ability to access productive or marginalized resources. The ultimate goal of the empowerment process is to make the citizens selfsufficient so that they can improve their living standards and optimize their resources. The powerlessness of members socially and economically becomes one of the obstacles for members to stand tall and sit equally low with their fellow brothers who have succeeded.

Conceptual studies on empowerment present many indicators of empowerment. Four of them involve the degree of empowerment (Suharto 2008), namely: (a) the level of awareness and the desire to change (power to), (b) the level of ability to increase capacity to gain access (power within), (c) the level of ability to face obstacles (power over), and (d) the level of cooperation and solidarity capabilities (power with).
The empowerment process is expected to make it more powerful and capable. Relation to indicators of empowered society. Sumardjo (1999) characterizes empowered communities, namely (1) being able to understand themselves and their potential, being able to plan (anticipating changes in the future), (2) being able to direct themselves, (3) having the power to negotiate, (4) having adequate bargaining power in making mutually beneficial cooperation, and (5) being responsible for their actions.

Community empowerment does not make people more dependent on various charity programs. Because, basically everything that is enjoyed, must be produced on its own business (the results of which can be exchanged with other parties). Thus, the ultimate goal is to establish the community, enable it, and build the ability to progress towards a better life continuously.

Empowering women, women are able to make decisions. Efforts to provide access to women to increase their capacity in all fields in order to improve the role of women in development. Empowered women are trained in skills according to talent and given revolving capital assistance, women who are empowered are those who have their own income and are able to finance their own lives.

Member Empowerment

Member empowerment is a basic element that allows a member to survive, and in a dynamic sense develop themselves and achieve progress. Community empowerment itself is the source of what in political insight is called national security. This means that if the community has a high economic capacity, then this is part of the national economic resilience.

Suharto (1997) states that powerlessness is due to several factors such as lack of economic security, lack of experience in the political arena, lack of access to information, lack of financial support, lack of training and physical and emotional tensions. Solomon in Suharto (1997) saw that powerlessness can come from internal and external factors. Powerlessness can come from negative self-assessors, negative interactions with the environment or stemming from blockages and obstacles that come from a larger environment.

Member empowerment can be realized through active participation of members facilitated by empowerment actors. The main objectives of empowerment are those who are weak and have no power, strength/ability to access productive or marginalized resources. The ultimate goal of the empowerment process is to make the citizens selfsufficient so that they can improve their living standards and optimize their resources. The powerlessness of members socially and economically becomes one of the obstacles for members to stand tall and sit equally low with their fellow brothers who have succeeded.

Conceptual studies on empowerment present many indicators of empowerment. Four of them involve the degree of empowerment (Suharto 2008), namely: (a) the level of awareness and the desire to change (power to), (b) the level of ability to increase capacity to gain access (power within), (c) the level of ability to face obstacles 
(power over), and (d) the level of cooperation and solidarity capabilities (power with).

The empowerment process is expected to make it more powerful and capable. Relation to indicators of empowered society. Sumardjo (1999) characterizes empowered communities, namely (1) being able to understand themselves and their potential, being able to plan (anticipating changes in the future), (2) being able to direct themselves, (3) having the power to negotiate, (4) having adequate bargaining power in making mutually beneficial cooperation, and (5) being responsible for their actions.

Community empowerment does not make people more dependent on various charity programs. Because, basically everything that is enjoyed, must be produced on its own business (the results of which can be exchanged with other parties). Thus, the ultimate goal is to establish the community, enable it, and build the ability to progress towards a better life continuously.

Empowering women, women are able to make decisions. Efforts to provide access to women to increase their capacity in all fields in order to improve the role of women in development. Empowered women are trained in skills according to talent and given revolving capital assistance, women who are empowered are those who have their own income and are able to finance their own lives. Member Empowerment

Member empowerment is a basic element that allows a member to survive, and in a dynamic sense develop themselves and achieve progress. Community empowerment itself is the source of what in political insight is called national security. This means that if the community has a high economic capacity, then this is part of the national economic resilience.

Suharto (1997) states that powerlessness is due to several factors such as lack of economic security, lack of experience in the political arena, lack of access to information, lack of financial support, lack of training and physical and emotional tensions. Solomon in Suharto (1997) saw that powerlessness can come from internal and external factors. Powerlessness can come from negative self-assessors, negative interactions with the environment or stemming from blockages and obstacles that come from a larger environment.

Member empowerment can be realized through active participation of members facilitated by empowerment actors. The main objectives of empowerment are those who are weak and have no power, strength / ability to access productive or marginalized resources. The ultimate goal of the empowerment process is to make the citizens selfsufficient so that they can improve their living standards and optimize their resources. The powerlessness of members socially and economically becomes one of the obstacles for members to stand tall and sit equally low with their fellow brothers who have succeeded.

Conceptual studies on empowerment present many indicators of empowerment. Four of them involve the degree of empowerment (Suharto 2008), namely: (a) the level of awareness and the desire to change (power to), (b) the level of ability to increase capacity to gain access (power within), (c) the level of ability to face obstacles (power over), and (d) the level of cooperation and solidarity capabilities (power with).

The empowerment process is expected to make it more powerful and capable. Relation to indicators of empowered society. Sumardjo (1999) characterizes empowered communities, namely (1) being able to understand themselves and their potential, being able to plan (anticipating changes in the future), (2) being able to direct themselves, (3) having the power to negotiate, (4) having adequate bargaining power in making mutually beneficial cooperation, and (5) being responsible for their actions.

Community empowerment does not make people more dependent on various charity programs. Because, basically everything that is enjoyed, must be produced on its own business (the results of which can be exchanged with other parties). Thus, the ultimate goal is to establish the community, enable it, and build the ability to progress towards a better life continuously.

Empowering women, women are able to make decisions. Efforts to provide access to women to increase their capacity in all fields in order to improve the role of women in development. Empowered women are trained in skills according to talent and given revolving capital assistance, women who are empowered are those who have their own income and are able to finance their own lives.

The results of different tests by looking at the probability obtained that there is no significant difference between the ability to access capital, access to information and market opportunities, business network access, and access to resources in 5 municipalities are still in the moderate category. This means that the empowerment of members with five four accesses is almost the same, except the ability to access technology that is still low is shown in Table 3 of 83.64 percent. This is due to the limited knowledge of today's technology, so it needs to be improved so that UPPKS members can optimize technology access.

Capital Access is very important to overcome barriers to the absence / lack of business capital, so that business activities can run. But the reality is that most UPPKS members have not been able to access the sources of capital provided through credit schemes at banks. This can be seen in Table 2 which states that most UPPKS members have moderate ability in terms of accessing capital, which is 68.58 percent. This is consistent with the results of a study by Sudarwan.et al. (2002), which found that some obstacles for small communities to obtain bank credit were the lack of collateral and the inability to make business proposals. As a result, many members prefer to borrow from moneylenders, so they are stuck at very high interest rates.

This condition can lead them to a situation of helplessness. Access to information and market opportunities (62.84 percent), smooth marketing depends on the attitude of business actors in addressing various opportunities and obstacles, as well as business actors. Not all businesses have the same mentality in addressing opportunities and obstacles. This attitude 
greatly affects marketing which automatically affects the business backwardness. Business network access (62.24 percent), meaning that UPPKS members who are able to access business networks through activities (1) establish relationships with fellow small-scale entrepreneurs (SMEs), medium and large in the same business field, (2) establish relationships with fellow small entrepreneurs, medium and large with different business fields to get support. Through access to the business network, UPPKS members can compete in a healthy manner through the creation of good services. Access resources $(83.94$ percent). This is due to the lack of available resources needed by UPPKS member businesses. Most UPPKS members in accessing resources that are not qualified are difficult and there is no effort to reach or get sufficient resources in quantity and quality; relying on ordinary (general) resources to be used, even though it is not in accordance with needs; and has no choice of resources, so that it becomes dependent on external resources. The following are the average score scores and different tests related to member empowerment.

Table 3 Distribution of UPPKS' Members based on Empowerment in 5 Districts in Jakarta

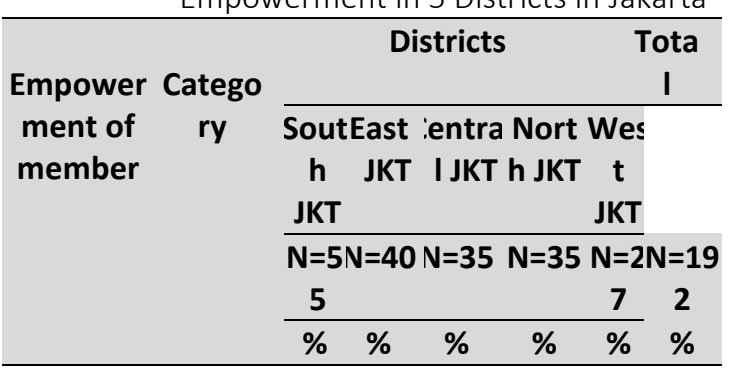

Access to Low $\quad 5,5 \quad 22,5$ 2C $42,940,126,3$

capital (8-11)

Average $=$ Mid

74,5 $75 \quad 77,1 \quad 57,159, ;$

12,67

(12-

$\begin{array}{lllll}15) & 20 & 2,5 & 2,9 & 8\end{array}$

68,5

High

$(>15)$

5,08

Access to Low

$9,32 \mathrm{C} \quad 17,3 \quad 11,618,(15,3$

informatio (15-18)

$\mathrm{n} \& \quad$ Mid

market (19-

$\begin{array}{llll}58,1 & 62,5 & 62,8 & 57\end{array}$

opportuni 22)

ty High

$32,6 \quad 17,5 \quad 2 \mathrm{C} \quad 31,5 \quad 74$ 62,8

Average $=(>22)$

7,4

20,7

Access to Low $(5-49,2$ 97,5 85,6 97,1 88.` 83,6

technolog 10) $50,8 \quad-14,4 \quad 2,911, ; \quad 4$

y $\quad$ Mid $\quad-\quad 2,5 \quad$ - $\quad$ - 15,8

Average (11- 6

$=9,03 \quad 16) \quad 0,5$

High

$(>16)$

Access to Low $\quad 9,1 \quad 2,5 \quad 25,7 \quad 14,3 \quad 18,(14,0$

Business (10-12)

network Mid 67,3 6C $62.9 \quad 65,7$ 70,

Average $=(13-$

$13,23 \quad 15)$

High

$(>15)$

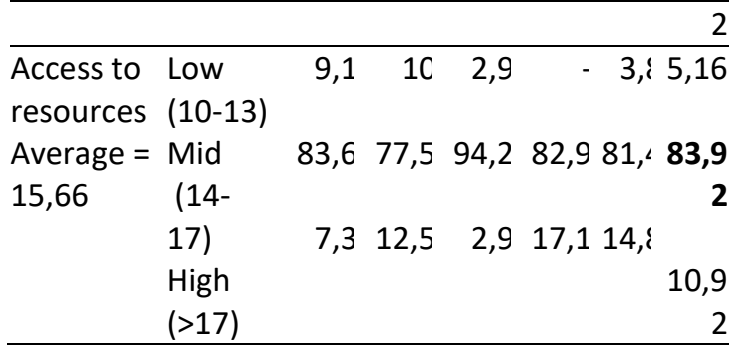

\section{Relationship between member empowerment and characteristics}

The relationship between the empowerment of members and their characteristics is a representation of the relationship between the characteristics of the members they possess and their empowerment. Variations in member characteristics include: age, level of education, family planning followed, training, income, capital owned, business units, business experience, and business motivation. The variables of member empowerment include; ability to access capital, information and market opportunities, technology, business networks, and resources. To examine the relationship between the empowerment of members and their characteristics, a correlation test was conducted. The following are the results of the correlation test between characteristics and empowerment in Table 4.

Tabel 4 Nilai koefisien korelasi antara karakteristik dan keberdayaan

\begin{tabular}{|c|c|c|c|c|c|}
\hline & $\begin{array}{l}\text { Access } \\
0 \\
\text { fapital }\end{array}$ & $\begin{array}{c}\text { Access to } \\
\text { information } \\
\text { \& market } \\
\text { opportunity }\end{array}$ & $\begin{array}{l}\text { Access to } \\
\text { technology }\end{array}$ & \begin{tabular}{|l|} 
Access \\
to \\
Business \\
network
\end{tabular} & $\begin{array}{l}\text { Access to } \\
\text { resource } \\
\text { s }\end{array}$ \\
\hline Age & $0.160^{*}$ & 0.28 & -0.34 & 0.62 & 0.19 \\
\hline $\begin{array}{l}\text { Educational } \\
\text { Level }\end{array}$ & 0.021 & -0.088 & $0.182^{*}$ & 0.56 & -0.058 \\
\hline $\begin{array}{l}\text { Type of } \\
\text { Family } \\
\text { Planning }\end{array}$ & 0.004 & -0.42 & -0.25 & -0.113 & -0.085 \\
\hline $\begin{array}{l}\text { Number of } \\
\text { training } \\
\text { followed }\end{array}$ & 0.046 & -0.083 & 0.062 & -0.043 & 0.140 \\
\hline ncome & 0.018 & -0.093 & 0.068 & -0.054 & 0.72 \\
\hline $\begin{array}{l}\text { Capital } \\
\text { Owned }\end{array}$ & 0.036 & -0.029 & $0.158^{*}$ & 0.092 & 0.005 \\
\hline $\begin{array}{l}\text { Business } \\
\text { Unit }\end{array}$ & 0.063 & 0.101 & -0.040 & -0.001 & 0.033 \\
\hline \begin{tabular}{|l} 
Business \\
Experiences
\end{tabular} & $0.151^{*}$ & 0.74 & 0.119 & -0.041 & 0.069 \\
\hline $\begin{array}{l}\text { Business } \\
\text { Motivation }\end{array}$ & 0.056 & -0.118 & $0.251^{* *}$ & 0.072 & 0.005 \\
\hline
\end{tabular}


Correlation test results show that there is a relationship between member characteristics and empowerment, for age variables and business experience shows a real relationship with the ability to access capital at the level of $\alpha=0.05$. The level of education, capital owned, and motivation to try to show a real relationship with the ability to access technology at the level of $\alpha=0.01$. That is, that the higher the level of education, the capital possessed, and the motivation to try, the higher the ability to access current technology. The higher the level of education a person has the wider knowledge. In general, someone who is better educated and has more knowledge, will be easier and better able to communicate well. The higher formal education, the higher the power in accessing technology.

\section{Family Empowerment Strategy towards Business Independence}

Strategy is the systematic steps taken in carrying out activities to get the maximum results expected. Handoko (2007) states that strategy in an organizational context is stated as a general program for the achievement of organizational goals. The formulation of strategies for enhancing member empowerment is the result of formulation through deductive studies and empirical testing.

Managing a home business requires the ability of the main actors, namely UPPKS members as the leading actors to achieve independence, the quality of which can be demonstrated by the ability of members in accessing several things to run their business. Therefore, a strategy for increasing member empowerment is needed in the face of competitiveness in the community. The enhancement of the empowerment of UPPKS members involves the ability of members to be able to access capital, information and market opportunities, technology, business networks and resources. The level of empowerment of members in the management of their business can further support the realization of their business independence, which are socioeconomically beneficial and ecologically feasible or accepted by the community.

The situation in the five municipalities shows that the empowerment of members in accessing capital, access to information and market opportunities, access to business networks, and the ability to access resources are still categorized as moderate. While the ability to access technology is categorized as low. Lack of empowerment of these members can be increased to high empowerment by paying attention to aspects that influence it, namely improving the empowerment process through improving education and training, especially in the field of technology. In order to implement more operationally the improvement of member empowerment towards business independence is carried out through three strategies, which are as follows:

1) Strategy for enhancing member empowerment through the empowerment process by increasing training and counseling,
2) Strategy for enhancing the empowerment of members through increased support of supporting institutions.

3) Strategy for increasing member empowerment through increasing group roles.

Strategies based on the results of this research cannot be separated from the policy and extension framework of BKKBN. Research, Developing that the learning process of the main actors and business actors in order to be willing and able to help and organize themselves in accessing capital, information and market repayment, technology, business networks, and other resources as an effort to increase productivity, business efficiency, income and welfare and increase independence ushanya.

Increase the role of trainers or extension agents as facilitators, motivators and catalysts (mediators). As a facilitator who assists members in making decisions that are best for themselves. The role of motivators, helping members to motivate themselves to want to learn and be willing to be more advanced. The role of catalyst, namely as a liaison between the interests of members and outside parties to establish mutually beneficial cooperation. The learning process is carried out using a participatory counseling approach oriented towards the learner / participant in setting goals, materials and counseling methods based on the needs and problems faced by UPPKS members. Sources of information not only come from trainers but also come from members so they can play an active and participatory role in tracing, exploring and discovering science / technology. Knowledge can be extracted from members who have more experience, knowledge of both life experience and business experience. Members' knowledge and experience can be discussed together.

The learning experience gained and directly practiced is known as learning by doing. Through direct practice, the level of understanding and memory about the material becomes higher. The forms of this method include demonstrations, simulations, training and field schools. Sharing methods are also often used in participatory counseling, which is a method of sharing experiences or knowledge between farmers or extension workers. Forms of this method include group discussions, platforms and tourist visits to other more advanced farmers in other areas who are considered successful. Counseling material developed from technical and non-technical aspects.

Support or role of groups is very important in making more creative innovations. Increasing the empowerment of members through groups becomes an effective learning media for members. Group members can interact with each other and share knowledge or experience. High cohesiveness in groups as reinforcement media applies creative innovation together.

\section{Empowerment improvement strategy}

The empowerment process contains two tendencies. The first is an empowerment process that emphasizes the process of giving or transferring some of the power, strength or ability to the community so that individuals 
become more empowered. This process can also be complemented by building material assets to support the development of their independence through an organization. The first tendency is called the primary tendency of empowerment, while the second tendency or secondary tendency emphasizes the process of stimulating, encouraging or motivating individuals to have the ability or empowerment to determine what their life choices are through a dialogue process.

In order to strengthen the position and role of the people's economy in the national economy, efforts are made to encourage accelerated structural change (structural adjustment or structural transformation). This structural transformation includes the process of change from the traditional economy to the modern economy, from a weak economy to a resilient economy, from subsistence economics to a market economy, from dependence to independence. This similar structural change requires fundamental steps which include allocating resources, strengthening institutions, and empowering human resources. By paying attention to various views including the biases towards the concept of empowerment, several strategic steps must be taken to develop the economy of UPPKS members through empowerment.

First, increasing access to productive assets. For the community, in particular the main productive capital UPPKS members are capital. Because this is very important in the process of increasing the empowerment of members so that there is a sustainability of the business they are doing. Capital ownership is increasingly difficult to obtain due to processes that are so complicated. This problem is the most fundamental problem in the framework of this structural transformation, it turns out is access to funds. The availability of adequate credit can create capital formation for the people's business so that it can increase production and income, and create a surplus that can be used to repay their credit and capital. The problem is the existence of banking prerequisites that make the lower-class society generally considered not bankable. This situation causes limited interaction between financial institutions that serve credit provision with small communities who need credit.

Second, strengthening the position of transactions and business partnerships. As producers and sellers, positions and strengths in the economy are very weak. They are price takers because they are very large with a very small market share. Furthermore, in their operations they usually face the power of large businesses that through unbalanced competition will take greater advantage. As a result, there is no incentive to improve quality, because the benefits of quality improvement will actually be drawn by large businesses. In addition, members in the group must also be organized to jointly market their products so that they strengthen their position. The cooperative container is very suitable for this activity, although it doesn't have to be the only one. Another important element is market information, regarding trends in demand in the market, price, quality, standards, etc. so that people's production is in line with market demand. The action review carried out based on collaboration between local universities and the government is one of the tangible manifestations of empowering the community to promote and facilitate the poor, poor families with the level of socio-economic development of the local community with a direct and proactive approach. The problems faced as a result of a study were immediately solved in the field.

Empowerment activities for each individual in an organization are a cycle of activities. These include as follows. First, to foster a desire for someone to change and improve, which is the starting point for the need for enrichment. Without a desire to change and improve, all community empowerment efforts undertaken will not receive attention, sympathy, or community participation. Second, fostering the willingness and courage to escape from pleasure / pleasure and or perceived obstacles, to then make decisions following empowerment in order to realize the expected changes and improvements. Third, develop willingness to follow or take part in empowerment activities that provide benefits or improve conditions.Fourth, increasing the role or participation in empowerment activities that have been perceived as benefits / improvements. Fifth, increased role and loyalty to empowerment activities, as indicated by the development of motivations to make changes. Sixth, increasing the effectiveness and efficiency of empowerment activities. Finally, it is by increasing competence to make changes through new empowerment activities.

\section{Group role enhancement strategy}

Using a group approach, because individually the poor are difficult to solve the problems they face. Also the scope of assistance is too broad if the handling is done individually. Therefore, as mentioned earlier, the group approach is the most effective, and seen from the use of resources is also more efficient. In addition, business partnerships between these groups with more advanced groups must be continuously nurtured and maintained mutually beneficial and advancing.

Similar community groups are the most effective for empowering members, because they grow and are rooted in their own members. Individually the poor are difficult to overcome obstacles that cause poverty. Together, they can strengthen each other and cover up weaknesses. Group dynamics and synergies are expected to produce value from individual efforts in groups.

\section{Strategy for increasing institutional support}

Community empowerment must involve all the potential that exists in society. Some aspects of which can be presented as follows:

First, the role of government is very important. This means that the government bureaucracy must be able to adjust to this mission. In this framework there are several efforts that must be done:

1) The bureaucracy must understand the aspirations of the people and must be sensitive to the problems faced by the people.

2) The bureaucracy must build people's participation. That is, give as much trust in the people as possible to improve themselves. Government officials help solve 
problems that cannot be overcome by the people themselves.

3) For this reason, the bureaucracy must prepare the community with the best, both their knowledge and the way they work, so that community empowerment efforts can be effective. This is part of social education efforts to enable people to build with independence.

4) The bureaucracy must open dialogue with the community. This openness and consultation is very necessary to increase public awareness, and so that officials can immediately help if there are problems that cannot be solved by the people themselves.

5) The bureaucracy must open the information path and access needed by the community that cannot be obtained by itself.

6) The bureaucracy must create regulatory instruments and regulate market mechanisms that favor weak groups of society.

To be able to carry out its mission, the bureaucracy must (1) increase its authority to the lowest level, (2) improve its quality, so as to truly be able to provide guidance and community empowerment. Especially the emphasis should be given to the apparatus at a level directly dealing with the community, both hierarchically, such as village and sub-district officials, as well as functional, such as PPL, teachers, doctors, and midwives.

Second, community organizations outside the community itself. Here what has the potential to play a major role is non-governmental organizations (NGOs), NGOs can function as government program implementers (representing the government), can become consultants. Third, community institutions that grow from and within the community itself, or are often referred to as local community organizations. This institution can be semi-formal or formal, such as LKMD, PKK or Karang Taruna, or who really grow from their own community such as arisan groups, sinoman groups, package groups and so on.

Fourth, cooperatives. The cooperative is a community economy that is specifically stated in the constitution as a business that is most suitable for Indonesian economic democracy. Cooperatives can be an effective vehicle for community empowerment efforts, by building modern humans but with the foundations of kinship and mutual cooperation that characterize Indonesian democracy. Cooperatives must be a target for the development of community groups that have been able to go beyond the initial stages of cooperation and joint work in groups. Formalization of groups as economic entities must be directed into cooperatives. However, for that group and its members must be really prepared, so that the form of cooperatives can truly support efforts to improve the business activities of the members carried out jointly.

Fifth, companion. The poor generally have limitations in developing themselves. Therefore, a companion is needed to guide the poor in an effort to improve their welfare. The companion is tasked with accompanying the formation and implementation of community groups as facilitators, communicators, or dynamicators. The scope of coaching carried out by the facilitators included efforts to improve the quality of human resources, namely the quality of the group members and administrators and the enhancement of members' business capabilities. For this purpose, the companion needs to know and conduct intensive communication with the group. The most effective companion is from members of the community itself, namely members of the community who have been more prosperous and have succeeded in their life and economic activities. In addition, independently and voluntarily colleges, community organizations, and other social institutions, such as NGOs, can also participate as mentors. To be able to carry out their duties effectively, the facilitator must be ready to work at all times, attend group meetings, organize training programs, and help groups in gaining access to the various services needed.

Sixth, community empowerment must be reflected in the planning process national development, as a flow from the bottom up that can help planning activities even at a modest level. What remains weak and must be strengthened in this planning process is the ability of planning at the village level. These efforts must include improving village institutions, strengthening human resources and developing the culture of rural communities who are responsive to change or can be called modernization of rural communities.

Seventh, the participation of more capable people, especially the business and private sectors. Community empowerment can be more optimal if there is a connection in business partnerships between those who have been able and those who are still lagging behind, especially through the provision of business capital for the development of the business of the poor. This model is being developed through the national movement of prosperous family savings (Takesra) and prosperous family business credit (Kukesra). In Takesra and Kukesra, the poor who belong to the category of preprosperous and prosperous families get savings injection assistance with the intention of getting used to saving and managing finances well. For the poor who have been able to save, they can apply for capital assistance in the form of Kukesra credit by submitting plans for productive activities. Capital assistance provided to the poor comes from people who have been better able. This effort whose initiative was taken by the government can be expanded, in various forms of direct partnership patterns, especially between private businesses and the people's economic business. The potential of the business community and society that is able to contribute to empowering the community is quite large, and needs to be developed, because in addition to its importance to strengthen the national economy, it will also strengthen national unity and unity, due to the strength of social solidarity.

\section{CONCLUSION}

There is a significant relationship between the empowerment of members and their characteristics, namely age, level of education, possessed capital and business motivation with the ability to access capital and the ability to access technology. To increased empowerment of members, this may be carried out by 
the following three strategies, namely, (1) enhancing the empowerment process with more specifics on more innovative and creative counseling and training; (2); strengthening group roles; and (3) strengthening institutional support to increase the business they undertake. Thus, much remain to be done by the government to improve the income of the poor family members under UPPKS programs.

\section{REFERENCES}

Astriana B.S. 2007. Family and Urban Empowerment: Family Cases in Sawir Sub-District and Jasinga District

Adnan, W. 2012. Efforts to Improve Family Welfare utilize National Rural Community Empowerment Program (PNPM) (Case of poor family in Pakedai II bay village, Pakedai Kubu raya subdistrict). PMISUNTAN-PSIS Journal of Thesis

Agussabti. 2002. "Independent Farmers in Taking Innovation Adoption Decisions (Case of Vegetable Farmers in West Java Province)". Bogor Dissertation: Bogor Agricultural University, Postgraduate Program.

Hardinsyah and Ujang Sumarwan. 1997. Family Economic Empowerment. Paper presented at IPADI National Seminar, 25-26 November 1997, Cibogo, Bogor. IPB. Bogor.

Lionberger, H.F. 1960. Adoption of New Ideas and Practices. Ames, Iowa: The Iowa State University Press

Mardikanto, T. 1993. Extension of Agricultural Development. Surakarta: Eleven March University Press.

Rianse, U, Abdi. 2008. Social and Economic Research Methodology. Bandung. (ID). Alfabeta

Rogers, Everret M., and D. Lawrence Kincaid .1981. Communication Networks. oward a New Paradigm for Reseach. New York: The Free Press

Slamet, M. 2003. In: Forming Patterns of Human Behavior Development. Edited by Yustina, I. and Adjat Sudradjat. Bogor: IPB Press.

Supriatna T. 1997. Bureaucracy Empowerment and Poverty Alleviation. Bandung (ID); Main Humanities Press.

Suharto. 2005. Poverty and Social Function: Case Study of Poor Households in Indonesia. Bandung: STKS Press

Suharto, Edi. 1997. Development, social policy and social work: spectrum of Thought, Bandung. Institute for Development Studies, STKS.

Sumardjo. 1999. Transformation of the Agricultural Extension Model Towards Farmer Self-Reliance Development (Case in West Java Province) (Dissertation). PS. Development Counseling Science, Pascasaarjana Program, Bogor Agricultural University. Bogor.

Sudarwan D., Helmi H., and Bahrin. 2002. Impact Study of Development Project for Increasing Income of Small Farmers and Fishermen in Bengkulu Province. Bengkulu: University of Bengkulu,
Postgraduate Program in Master of Education Management. 